\title{
Thumb autoamputation following tourniquet syndrome
}

\author{
Robert Brian McGrath ำ $, 1,2$ Kevin C Cahill, ${ }^{3}$ Patricia A Eadie, ${ }^{3}$ Sinead Brigid Harty ${ }^{1}$
}

${ }^{1}$ Department of General Paediatrics, Children's Health Ireland at Crumlin, Dublin, Ireland

2Department of Paediatrics, University Hospital Galway, Galway, Ireland

${ }^{3}$ Department of Plastic Surgery, Children's Health Ireland at Crumlin, Dublin, Ireland

\section{Correspondence to} Dr Robert Brian McGrath; robert.mcgrath6@icloud.com

Accepted 9 March 2020

\section{DESCRIPTION}

A 12-month-old boy presented to the paediatric emergency department (PED) with ischaemic necrosis of the distal phalanx of the left thumb as a result of tourniquet syndrome.

Six days prior to presentation, an adhesive bandage had been applied to the digit to discourage thumb sucking. His mother described crying and irritability, and when the dressing was removed 48 hours after application, the infant's mother noted the digit to be shrivelled and mottled. The following day, the area began to blister and he was brought to his general practitioner for review, where hospital attendance was advised. The infant presented to the PED 72 hours later.

Examination of the left thumb revealed dry necrosis of the nailbed and distal phalanx (figure 1). The infant was admitted under the joint care of the plastic surgery and general paediatric teams. The injury was initially managed conservatively. The distal phalanx subsequently autoamputated and formal surgical debridement and terminalisation at the level of the interphalangeal joint was undertaken. At follow-up 12 months later, the injury had healed well with a satisfactory functional outcome (figure 2).

The severity of the injury coupled with the delay in presentation raised suspicion of neglect or nonaccidental injury, and the case was referred to the

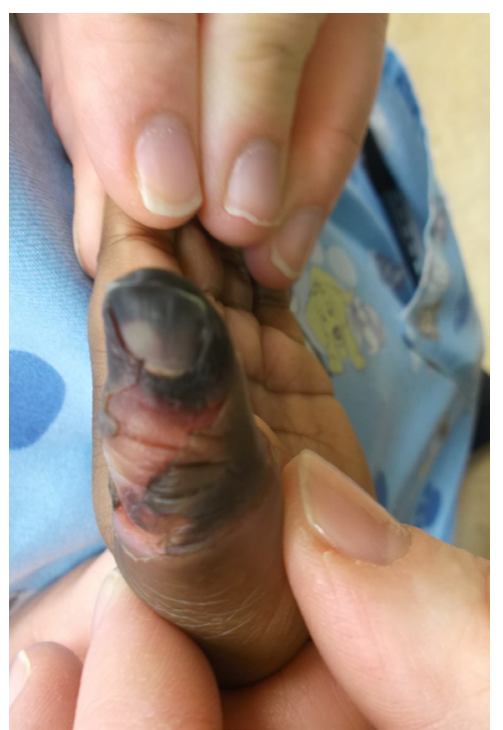

Figure 1 Clinical photograph from initial presentation demonstrating dry necrosis of the nailbed and distal phalanx of the left thumb extending $1 \mathrm{~cm}$ proximal to the nail fold with a visible tourniquet mark at the interphalangeal joint.

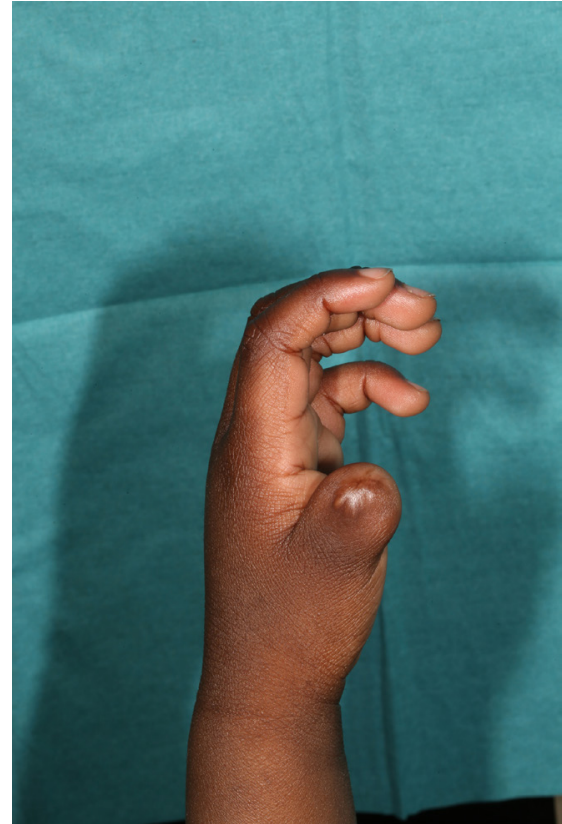

Figure 2 Clinical photograph taken 12 months post terminalisation at the level of the interphalangeal joint.

Medical Social Work Department. The history given by both parents was consistent with the presenting injury. No other concerning injuries or previous hospital presentations were noted, and appropriate child-parent interaction was noted throughout. A child protection case conference found that the injury was unintentional and that the infant was not at on-going risk of significant harm through neglect. A family support plan was put in place on discharge to the community.

This case represents a variant on tourniquet syndrome. This syndrome is more commonly associated with hair or thread wrapped around a distal appendage, also known as hair-thread tourniquet syndrome (HTTS). ${ }^{1}$ Regardless of the cause of constriction, it is regarded as a surgical emergency as circumferential constriction impedes lymphatic drainage with resultant venous outflow obstruction and oedema. Raised interstitial pressures then restrict arterial supply causing ischaemia and associated pain. ${ }^{2}$ If it is not possible to remove the tourniquet in the PED, general anaesthetic and removal in theatre may be required. ${ }^{3}$ In cases of significant vascular compromise necrosis and autoamputation may occur as in the case illustrated here.

A large single-centre retrospective study of HTTS performed in a major children's hospital analysed 81 cases over a 10 -year period. In $85.2 \%$ of cases, the toes were affected, the fingers in $6.2 \%$ and 
external genitalia in $8.6 \% .{ }^{3}$ Infants and young children are most commonly affected with one retrospective study of admissions to a PED reporting a mean age of $5.5 \pm 4$ months. ${ }^{4}$

Due to the insidious nature of this syndrome, an awareness of and high index of suspicion for this condition are required for timely detection. Added vigilance is required in the case of preverbal children and those with speech or learning difficulties who may not be able to express discomfort easily.

\section{Learning points}

- Tourniquet syndrome is a surgical emergency that if not promptly treated can result in significant vascular compromise and loss of an appendage.

- A high index of suspicion is required for timely detection especially in those who cannot express disomfort easily, such as preverbal children, and those with speech or learning difficulties.
Contributors RBM obtained patient consent, conducted chart review, literature review and drafted and revised the paper. KCC contributed to literature review and revised the draft paper. PAE and SBH were the senior clinicians responsible for the management of this case and revised the draft paper.

Funding The authors have not declared a specific grant for this research from any funding agency in the public, commercial or not-for-profit sectors.

Competing interests None declared.

Patient consent for publication Parental/guardian consent obtained.

Provenance and peer review Not commissioned; externally peer reviewed.

\section{ORCID iD}

Robert Brian McGrath http://orcid.org/0000-0002-0605-4064

\section{REFERENCES}

1 Barton DJ, Sloan GM, Nichter LS, et al. Hair-thread tourniquet syndrome. Pediatrics 1988:82:925-8.

2 Wang M, Schott J, Tunnessen WW. Picture of the month. Arch Pediatr Adolesc Med 2001:155:515-6.

3 Bean JF, Hebal F, Hunter CJ. A single center retrospective review of hair tourniquet syndrome and a proposed treatment algorithm. J Pediatr Surg 2015;50:1583-5.

4 Claudet I, Pasian N, Debuisson C, et al. Tourniquet syndrome: interest of a systematic analysis of families' social conditions to detect neglect situations. Child Abuse Negl 2009:33:569-72.

Copyright 2020 BMJ Publishing Group. All rights reserved. For permission to reuse any of this content visit

https://www.bmj.com/company/products-services/rights-and-licensing/permissions/

BMJ Case Report Fellows may re-use this article for personal use and teaching without any further permission.

Become a Fellow of BMJ Case Reports today and you can:

- Submit as many cases as you like

- Enjoy fast sympathetic peer review and rapid publication of accepted articles

- Access all the published articles

Re-use any of the published material for personal use and teaching without further permission

Customer Service

If you have any further queries about your subscription, please contact our customer services team on +44 (0) 2071111105 or via email at support@bmj.com.

Visit casereports.bmj.com for more articles like this and to become a Fellow 